\section{Eradication of a Mature Methicillin- Resistant Staphylococcus aureus (MRSA) Biofilm From Acrylic Surfaces}

Karen Tereza Altieri, Paula Volpato Sanitá, Ana Lucia Machado, Eunice Teresinha Giampaolo, Ana Cláudia Pavarina, Janaina Habib Jorge, Carlos Eduardo Vergani
Department of Dental Materials and Prosthodontics, Araraquara School of Dentistry, UNESP - Univ Estadual Paulista, Araraquara, SP, Brazil

Correspondence: Prof. Dr. Carlos Eduardo Vergani, Rua Humaitá, 1680, 14801-903 Araraquara, SP, Brasil. Tel: +55-16-33016547. Fax: +55-16-3301-6406. email: vergani@foar.unesp.br

\begin{abstract}
Methicillin-resistant Staphylococcus aureus (MRSA) can grow as structured biofilm in different surfaces, including oral mucosa and denture surfaces. Such biofilms can be released into the oral fluids and aspirated, causing systemic infections such as aspiration pneumonia. This study evaluated the efficacy of two disinfectant solutions and microwave irradiation in disinfecting acrylic specimens contaminated with MRSA biofilm. Thirty-six acrylic specimens were made, sterilized and contaminated with MRSA $\left(10^{7} \mathrm{cfu} / \mathrm{mL}\right)$. After incubation $\left(37^{\circ} \mathrm{C} / 48 \mathrm{~h}\right)$, the specimens were divided into 4 groups: not disinfected (positive control); soaking in $1 \%$ sodium hypochlorite for $10 \mathrm{~min}$; soaking in $2 \%$ chlorhexidine gluconate for $10 \mathrm{~min}$; and irradiating by microwave for $3 \mathrm{~min}$ at $650 \mathrm{~W}$. The viability of cells was evaluated by XTT reduction method. All specimens from the positive control group showed biofilm formation after $48 \mathrm{~h}$ incubation. The mean absorbance value of the control specimens was 1.58 (OD at $492 \mathrm{~nm}$ ). No evidence of biofilm formation was observed on specimens after the disinfection methods. Disinfection by soaking in $1 \%$ sodium hypochlorite and $2 \%$ chlorhexidine gluconate and irradiating by microwaves resulted in 100\% reduction of MRSA biofilm metabolism. The use of chemical solutions and microwave irradiation was shown to be effective for eradicating mature MRSA biofilms on acrylic resin specimens.
\end{abstract}

Key Words: MRSA, acrylic resins, disinfection, microwave irradiation, disinfectants, denture cleansers.

\section{Introduction}

The oral cavity is a complex environment composed of tissues with different origins, structures and functions. A myriad of commensal bacteria, fungi and viruses colonize these sites. This is particularly important in immunocompromised and elderly patients, whose oral hygiene is poor (1). Among these microorganisms, Staphylococcus aureus strains have been isolated from oral cavity, saliva and oral appliances, such as complete dentures (2). With the emergence of methicillin resistance, $S$. aureus has received even more attention as bacteremia involving methicillin-resistant S. aureus (MRSA) has been considered a global public health problem. A high percentage of nosocomial infections in patients in intensive care units are due to MRSA, which has been related to more severe and virulent infections and to a higher mortality rate (3).

Investigations have demonstrated that MRSA is able to adhere on a wide variety of substrates, including denture acrylic surfaces (4). Thus, the dentures may also function as a reservoir of this pathogen, favoring the oral colonization by MRSA. This microorganism can also readily form biofilms, which are structured communities of microorganisms enclosed in a self-produced hydrated polymeric matrix. Biofilm formation by MRSA has important clinical repercussions because the biofilms are more resistant to the host immune response and more tolerant to antimicrobials. This frequently compromises the effectiveness of therapies by giving rise to persistent and relapsing infections. Moreover, fragments of biofilm may be dislodged from denture surfaces and carried further into the lung, resulting in systemic infections such as aspiration pneumonia (5). A high prevalence of respiratory pathogens on the surface of removable dentures has been reported, suggesting that poor denture hygiene may be related to the development of aspiration pneumonia (6). In fact, a clinical study showed that the incidence of pneumonia and death decreased in patients receiving an intensive oral healthcare program (7).

Considering the information above, a strict routine of oral and denture hygiene program is essential to prevent the spread and recurrence of local and systemic infections associated with MRSA. Usually, denture hygiene of dependent elderly individuals is extremely poor, mainly because of manual dexterity impairment (1). Therefore, different methods of denture disinfection have been proposed to inactivate the microorganisms from the denture surface and improve the quality of oral hygiene of these patients. In this context, several chemical agents have been recommended and, among them, sodium hypochlorite 
$(\mathrm{NaOCl})$ and chlorhexidine gluconate $(\mathrm{CHX})$ have been widely used (8-10).

$\mathrm{NaOCl}$ is considered useful as denture cleanser solution because it inactivates bacterial plaque, removes stains, and inhibits calculus formation on dentures $(8,11)$. CHX is another agent commonly recommended for denture disinfection because it possesses a broad spectrum of antimicrobial activity (8-10). In addition to these chemical methods of disinfection, physical methods have also been recommended for denture disinfection. In this context, microwave irradiation received substantial attention for denture disinfection. Several in vitro studies $(12,13)$ showed that microwave irradiation for $3 \mathrm{~min}$ at 650 $W$ is an effective method for killing a wide variety of microorganisms, including $S$. aureus and intrinsically resistant species of Candida (C. glabrata and C. krusei). Moreover, an in vivo study (2) showed that this disinfection method was effective for inactivating $S$. aureus on denture biofilms of 30 individuals. Despite its effectiveness against several microorganisms, the literature does not address the effectiveness of microwave irradiation on MRSA in vitro biofilms.

This in vitro study evaluated the effectiveness of $\vec{\sigma}$ two chemical solutions $(1 \% \mathrm{NaOCl}$ and $2 \% \mathrm{CHX})$ and microwave irradiation ( $3 \mathrm{~min}$ at $650 \mathrm{~W}$ ), for inactivating mature MRSA biofilms. The tested hypothesis was that there would be no differences among the disinfection methods.

\section{Material and Methods}

\section{Preparation of Acrylic Resin Specimens}

Thirty-six specimens were fabricated from an acrylic denture base resin (VipiWave; VIPI Indústria e Comércio Exportação e Importação de Produtos Odontológicos Ltda, Pirassununga, SP, Brazil) using a conventional flasking and pressure-pack technique. The resin disks were fabricated from a stainless steel mold with a breakaway compartment $(10 \times 2 \mathrm{~mm})$. This metal mold was invested in the flask in dental stone sandwiched between two glass slabs. For each specimen, $1 \mathrm{~g}$ of powder and $0.47 \mathrm{~mL}$ of monomer liquid were mixed and processed according to the manufacturer's instructions. The mixture was packed into the molds, a trial pack was completed and excess material was removed. A final pack was performed and held for $15 \mathrm{~min}$. The denture base acrylic resin was processed in a $500 \mathrm{~W}$ domestic microwave oven for $20 \mathrm{~min}$ at 20\% power, followed by 5 $\min$ at $90 \%$ power. The flasks were allowed to bench cool at room temperature, the specimens were deflasked, and excess flash was removed with a sterile bur (Maxi-Cut; Les Fils d'August Maillefer SA, Ballaigues, Switzerland). After $48 \mathrm{~h}$ of storage in distilled water at $37^{\circ} \mathrm{C}$, all specimens were sterilized with ethylene oxide $(12,13)$.

\section{Bacterial Culture and Suspension}

The standard strain of MRSA used in this study was obtained from the American Type Culture Colection (ATCC 33591). The isolate was maintained in Tryptic Soy Broth - TSB (Acumedia Manufactures Inc., Baltimore, MD, USA) medium and frozen at $-70{ }^{\circ} \mathrm{C}$ until use. To prepare the bacterial inoculum, a loopful of the stock culture was streaked onto Mannitol Salt Agar (Acumedia Manufactures Inc.) and incubated at $37^{\circ} \mathrm{C}$ for $48 \mathrm{~h}$. Two loopfuls of this culture were transferred to $20 \mathrm{~mL}$ of TSB and incubated under agitation at $37^{\circ} \mathrm{C}$ overnight (12). Cells of the resultant culture were harvested and washed twice with phosphatebuffered saline (PBS, pH 7.2) by centrifugation at $5,000 \mathrm{~g}$ for 5 min. MRSA suspensions were resuspended in TSB and spectrophotometrically standardized at an optical density at $600 \mathrm{~nm}$ to a concentration of $10^{7}$ cells/mL (12).

\section{Biofilm Development}

Biofilms were developed on the acrylic resin specimens placed inside pre-sterilized flat-bottomed 24-well microtiter plates. Aliquots of $2 \mathrm{~mL}$ of the standardized MRSA cell suspension were transferred into each well containing one specimen. The plates were incubated for $90 \mathrm{~min}$ at $37^{\circ} \mathrm{C}$ in an orbital shaker at $75 \mathrm{rpm}$ (adhesion phase). Thereafter, the non-adherent cells were removed from the specimens by gently washing twice with $2 \mathrm{~mL}$ PBS. For the biofilm phase, $2 \mathrm{~mL}$ of sterile TSB was added to each well and the plates were incubated shaking for $48 \mathrm{~h}\left(37^{\circ} \mathrm{C}\right.$ at $\left.75 \mathrm{rpm}\right)$ as described above. At $24 \mathrm{~h}$ incubation, the TSB medium was removed, specimens were washed twice with PBS, and an equal volume of fresh TSB was added. The microtiter plates were then incubated for further $24 \mathrm{~h}$, resulting in a final incubation time of $48 \mathrm{~h}$.

\section{Disinfection Procedures}

The 36 specimens were randomly divided into 4 groups $(n=9)$ : positive control and experimental groups. In the positive control group, specimens were immersed in distilled water for $10 \mathrm{~min}$. In the experimental groups, the specimens were disinfected by soaking in $1 \% \mathrm{NaOCl}$ and 2\% CHX followed by microwave irradiation. Briefly, contaminated specimens of $\mathrm{NaOCl}$ and $\mathrm{CHX}$ groups were individually transferred to pre-sterilized flat-bottomed 24-well microtiter plates and soaked in $2 \mathrm{~mL}$ of $1 \%$ $\mathrm{NaOCl}$ (Labimpex Indústria e Comércio de Produtos para Laboratório Ltda., Diadema, SP, Brazil) or 2\% CHX (Deg Importação de Produtos Químicos Ltda., São Paulo, SP, Brazil), respectively, for $10 \mathrm{~min}$. In the microwave irradiation group, the specimens were transferred to a beaker with $200 \mathrm{~mL}$ of sterile distilled water. Each beaker was placed on the rotational plate in a domestic microwave oven and irradiated at $650 \mathrm{~W}$ for $3 \mathrm{~min}(12,13)$. 


\section{XTT Assay}

The effect of the disinfection procedures on the biofilm viability was evaluated by XT reduction assay. This method correlates well with other quantitative techniques such as ATP and CFU assays and thus it has been widely used to evaluate fungal adhesion and biofilm formation. XT (Sigma, St. Louis, MO, USA) was prepared in ultrapure water at a final concentration of $1 \mathrm{mg} / \mathrm{mL}$. The solution was filter sterilized and stored at $-70^{\circ} \mathrm{C}$ until use. Menadione solution (Sigma) was prepared in acetone at $0.4 \mathrm{mM}$ immediately before each assay. Control and disinfected specimens were transferred to well microtiter plates, washed twice with $2 \mathrm{~mL} P B S$, and re-transferred to new wells with a mixture of $1580 \mu \mathrm{L}$ PBS with $200 \mathrm{mM}$ glucose, $400 \mu \mathrm{L} \mathrm{XT}$ and $20 \mu \mathrm{L}$ menadione in each well. The plates were incubated for $3 \mathrm{~h}$ in the dark at $37^{\circ} \mathrm{C}$. An aliquot of $1 \mathrm{~mL}$ of the solution of each well was transferred to an eppendorf and centrifuged at 5,000 $\mathrm{g}$ for $2 \mathrm{~min}$. The colorimetric change of the supernatant was measured using a microtiter plate reader (Thermo Plate TP Reader) at $492 \mathrm{~nm}$. All experiments were performed in triplicate on three independent occasions.

\section{Statistical Analysis}

The effect of the disinfection methods on the metabolic activity of the biofilm was measured as the percentage reduction (\%) in relation to the XTT absorbance values of the control. The results obtained from the positive control and experimental groups were transferred to a computer spreadsheet program (Excel ${ }^{\oplus}$ 2007, Microsoft Corporation, USA) and descriptive statistics was employed.

\section{Results}

All positive control specimens contaminated with MRSA showed biofilm formation after $48 \mathrm{~h}$ incubation. The mean absorbance (OD at $492 \mathrm{~nm}$ ) obtained from the positive control was 1.58. Disinfected specimens contaminated with MRSA showed no evidence of biofilm formation, regardless of the disinfection protocol. All methods of disinfection reduced $100 \%$ of the biofilm viability (absorbance) when compared to the positive control. The viability of MRSA

Table 1. Mean of absorbance (OD) and percentage reduction (\%) from positive control and experimental groups

\begin{tabular}{lcc}
\hline Group & XTT OD (SD) & $\%$ \\
\hline Positive control & $1.58(0.27)$ & NA \\
1\% sodium hypochlorite & $0.00(0.00)$ & 100 \\
$2 \%$ chlorhexidine gluconate & $0.00(0.00)$ & 100 \\
Microwave irradiation & $0.00(0.00)$ & 100 \\
\hline
\end{tabular}

SD: standard deviation; NA: not applicable. biofilm in relation to absorbance, percentage reduction and standard deviation for all evaluated groups are presented in Table 1. The standard deviation was zero for all disinfected groups, in which no metabolic activity was observed.

\section{Discussion}

The hypothesis that there would be no differences among the disinfection methods evaluated in the present study was accepted. The results showed that all methods of disinfection reduced $100 \%$ of the biofilm viability when compared to the positive control. These findings agree with recent data from a previous in vitro study, in which complete dentures contaminated with planktonic MRSA were disinfected by the same disinfection protocols (14). Despite the similar results, there are some differences in the methodology used in these two microbiological studies. The most striking difference is that Altieri et al. (14) tested the disinfection protocols against planktonic MRSA cells rather than mature MRSA biofilms. Several researchers also demonstrated that planktonic MRSA were killed rapidly by means of antimicrobial agents $(9,10)$. However, others showed that the established MRSA biofilms were more resistant to killing by these agents (9). A special characteristic of biofilms is their high tolerance to antibiotics and disinfectants as compared to planktonic cells. It has been suggested that the poor penetration of the antimicrobial agents into the complex biofilm matrix is not the only hurdle to overcome in the eradication of biofilm. Bacteria within the biofilm can also differentiate into "protected phenotypic states", allowing these sessile bacteria to further resist standard antibiotic strategies (15). In addition to their increased resistance after the maturation process, the detachment of a cell from the biofilm mass may initiate a new cycle of biofilm formation elsewhere, perpetuating the infection. The results of this study presented effective methods for the eradication of mature MRSA biofilms, which can be useful in reducing the burden of disease associated with MRSA biofilms worldwide.

In the present study, chemical disinfection by $1 \%$ $\mathrm{NaOCl}$ and $2 \% \mathrm{CHX}$ was effective against MRSA biofilm. These results are consistent with findings in the literature. The results also showed that there were no differences among the chemical methods and microwave disinfection. Denture disinfection strategies by means of chemical solutions have been frequently recommended due to their effectiveness in inhibiting several microorganisms. Of the available chemical disinfectants, both $\mathrm{NaOCl}$ and $\mathrm{CHX}$ have been used for denture disinfection due to their ability to reduce the microbial growth and adherence to dental materials. $\mathrm{NaOCl}$ is used as a traditional denture disinfectant because of its effectiveness in killing a wide range of microorganisms (8). In the present study, $10 \mathrm{~min}$ 
of immersion in $1 \% \mathrm{NaOCl}$ solution reduced $100 \%$ of the MRSA biofilm viability on acrylic specimens when compared to the positive control. For MRSA biofilm inactivation, Lee et al. (4) reported that MRSA biofilms were difficult to eradicate unless $2 \% \mathrm{NaOCl}$ was used. This could be explained by the time of biofilm maturation used in their study $(120$ h) and the lower immersion time (1 min). Despite being an effective disinfectant, $\mathrm{NaOCl}$ has been frequently related to corrosive effects on the frameworks, color changes of denture acrylic resin and changes in the flexural strength of denture base resins $(16,17)$.

As seen for $1 \% \mathrm{NaOCl}, 2 \% \mathrm{CHX}$ reduced $100 \%$ of the biofilm viability after $10 \mathrm{~min}$ of immersion. While $\mathrm{NaOCl}$ dissolves mucin and other organic substances of the biofilm, causing dissolution of the polymer structure (11), CHXacts on the cellular membrane, causing loss of intracellular material, respiratory inhibition, and cytoplasmic coagulation (18). Another study demonstrated the efficacy of $\mathrm{CHX}$ against a wide range of bacteria from the genera Streptococcus, Pseudomonas, Bacillus, Acinetobacter, Escherichia, and Staphylococcus, including MRSA (10). Smith and Hunter (9) established a protocol of disinfection in which $24 \mathrm{~h}$ of immersion at 4\% concentration solution was effective $\dot{s}$ against planktonic cells of MRSA. Other studies also found that $2 \% \mathrm{CHX}$ was effective to erradicate planktonic cells of MRSA (10) and MSSA biofilm (8), after 3 and 10 min of immersion, respectively. Despite the difference in concentration and time of immersion, these results are consistent with those found here, where the metabolism of mature biofilms was completely inhibited. Nevertheless, the use of $\mathrm{CHX}$ solution has been related to some side effects, such as discoloration of tooth surfaces, labial and buccal mucosa, tongue (19) and denture acrylic resin (17). Some components of these solutions can also penetrate into the material and may not be completely removed by rinsing (20), which may have toxic effects when applied in clinical practice as a routine disinfection method (21).

The ability of bacteria to develop resistance to antimicrobial agents is a critical challenge. Resistance of MRSA to antiseptics, including $\mathrm{CHX}$, has been demonstrated (22). In addition, some problems have been encountered with the use of these chemical solutions since they may affect unfavorably the physical properties of denture acrylic resins $(16,17)$. Such disadvantages are clearly a concern, since a disinfection method should be effective without having any detrimental effect on denture materials. In order to overcome these limitations, the use of alternative methods of disinfection has been encouraged. Microwave irradiation has been considered a feasible alternative method for denture disinfection because it needs no special storage, has no expiration date and, mainly, given that it is a physical method of disinfection, the emergence of resistant microorganisms would be avoided. In the present study, 3 min of microwave irradiation at $650 \mathrm{~W}$ reduced $100 \%$ of the MRSA biofilm viability when compared to the positive control. The killing action of this protocol was previously demonstrated against methicillin-susceptible $S$. aureus (MSSA), either in in vitro (12) or in in vivo studies (2). In a more recent in vitro study, MRSA adhered to simulated dentures was also killed by 3 min of microwave irradiation at $650 \mathrm{~W}$ (14). Nevertheless, to the authors' knowledge, this is the first study reporting the effectiveness of this method in killing mature MRSA biofilms. Two potential explanations have been considered about microbial killing action of microwave irradiation: the thermal effect and non-thermal effect. The microorganisms can absorb microwave thermal heat at a much greater rate than the surrounding liquid medium or the microwaves can cause dielectric relaxation, ionic conductivity and biopolymer alteration (23). Injury of $S$. aureus cells exposed to microwave irradiation at sublethal temperature has shown to be greater than after conventional heating (24). The exposition of Bacillus subtilis and Escherichia coli suspensions to microwave irradiation caused reduction on viable cell counts and increased the leaching of DNA and protein, suggesting cell membrane cleavage (25). Similarly, a previous study demonstrated (23) that $C$. albicans cells could be irreversibly damaged and inactivated by microwave irradiation at $650 \mathrm{~W}$ during $6 \mathrm{~min}$. A combination of these mechanisms is probably responsible for the effect of microwave irradiation observed in the present study.

The adverse consequences associated with MRSA colonization suggest that even a partially effective decolonization could be useful in reducing the burden of disease associated with MRSA biofilms. The outcomes produced by the three disinfection methods proposed in this study suggest that they could be used by private dental offices, institutions and hospitals in which elderly denture wearers with special needs are treated. Patients in these conditions usually have poor oral health due to difficulties in maintaining a sufficient level of personal oral hygiene and difficulties in accessing professional dental care, rendering them more susceptible to MRSA-related infections. The limitations of this in vitrostudy were mainly related to the fact that it evaluated only the metabolism of the MRSA biofilm. Thus, it could be of interest to evaluate other complementary parameters of the biofilm behavior after the disinfection procedures, such as a quantitative and qualitative biomass analysis and viability of the cells.

\section{Resumo}

Staphylococcus aureus resistente à meticilina (MRSA, do inglês methicillinresistant Staphylococcus aureus) pode crescer como biofilme estruturado em diferentes superfícies, incluindo mucosa bucal e superficies de próteses. 
Estes biofilmes podem se dispersar nos fluidos orais e ser aspirados, causando infecções sistêmicas, como a pneumonia aspirativa. Este estudo avaliou a eficácia de duas soluções desinfetantes e irradiação por microondas na desinfecção de corpos-de-prova acrilicos contaminados com biofilme de MRSA. Trinta e seis espécimes de resina acrilica foram fabricados, esterilizados e contaminados com MRSA ( $\left.10^{7} \mathrm{ufc} / \mathrm{mL}\right)$. Após a incubação $\left(37^{\circ} \mathrm{C} / 48 \mathrm{~h}\right)$, os espécimes foram divididos em quatro grupos: não desinfetados (controle positivo); imersos em hipoclorito de sódio $1 \%$ por $10 \mathrm{~min}$; imersos em gluconato de clorexidina $2 \%$ por 10 min e irradiados por microondas durante $3 \mathrm{~min}$ a $650 \mathrm{~W}$. A viabilidade das células foi avaliada pelo método de redução de XTT. Todos os espécimes do grupo controle apresentaram formação de biofilme após $48 \mathrm{~h}$ de incubação. 0 valor médio de absorbância destes espécimes foi de 1.58 (OD a $492 \mathrm{~nm}$ ). Nenhuma evidência de formação de biofilme foi observada em todas as amostras desinfetadas. A desinfecção em hipoclorito de sódio 1\%, gluconato de clorexidina $2 \%$ e irradiação em microondas resultou em 100\% de redução do metabolismo do biofilme de MRSA. 0 uso de soluções químicas e irradiação em microondas mostrou-se eficaz na eliminação do biofilme maduro de MRSA sobre corpos-de-prova de resina acrílica.

\section{References}

1. Komulainen K, Ylöstalo P, Syrjälä AM, Ruoppi P, Knuuttila M, Sulkava $\mathrm{R}$, et al.. Oral health intervention among community-dwelling older people: a randomised 2-year intervention study. Gerodontology 2013. [Epub ahead of print. DOI: 10.1111/ger.12067].

2. Ribeiro DG, Pavarina AC, Dovigo LN, Palomari Spolidorio DM, Giampaolo ET, Vergani CE. Denture disinfection by microwave irradiation: a randomized clinical study. J Dent 2009;37:666-672.

3. Taylor AR. Methicillin-resistant Staphylococcus aureus infections. Prim Care 2013;40:637-654.

4. Lee D, Howlett J, Pratten J, Mordan N, McDonald A, Wilson M, et al.. Susceptibility of MRSA biofilms to denture-cleansing agents. FEMS Microbiol Lett 2009;291: 241-246.

5. Raghavendran K, Mylotte JM, Scannapieco FA. Nursing homeassociated pneumonia, hospital-acquired pneumonia and ventilatorassociated pneumonia: the contribution of dental biofilms and periodontal inflammation. Periodontology 2000 2007;44:164-177.

6. Sumi Y, Miura H, Sunakawa M, Michiwaki Y, Sakagami N. Colonization of denture plaque by respiratory pathogens in dependent elderly. Gerodontology 2002;19:25-29.

7. Yoneyama T, Yoshida $\mathrm{M}$, Ohrui T,Mukaiyama $\mathrm{H}$, Okamoto $\mathrm{H}$, Hoshiba $\mathrm{K}$, et al.. Oral care reduces pneumonia in older patients in nursing homes. J Am Geriatr Soc 2002;50:430-433.

8. da Silva FC, Kimpara ET, Mancini MN, Balducci I, Jorge AO, Koga-Ho CY. Effectiveness of six different disinfectants on removing five microbial species and effects on the topographic characteristics of acrylic resin. J Prosthodont 2008;17:627-633.

9. Smith $K_{1}$ Hunter IS. Efficacy of common hospital biocides with biofilms of multi-drug resistant clinical isolates. J Med Microbiol 2008;57:966973.

10. DeBaun B. Evaluation of the antimicrobial properties of an alcohol-free 2\% chlorhexidine gluconate solution. AORN J 2008;87:925-933.

11. Estrela C, Estrela CR, Barbin EL, Spanó JC, Marchesan MA, Pécora JD.
Mechanism of action of sodium hypochlorite. Braz Dent J 2002;13:113117.

12. Dovigo LN, Pavarina AC, Ribeiro DG, Oliveira JA, Vergani CE, Machado AL. Microwave disinfection of complete dentures contaminated in vitro with selected bacteria. J Prosthodont 2009;18:611-617.

13. Sanitá PV, Vergani CE, Giampaolo ET, Pavarina AC, Machado AL. Growth of Candida species on complete dentures: effect of microwave disinfection. Mycoses 2009;52:154-160.

14. Altieri KT, Sanitá PV, Machado AL, Giampaolo ET, Pavarina AC, Vergani CE. Effectiveness of two disinfectant solutions and microwave irradiation in disinfecting complete dentures contaminated with methicillin-resistant Staphylococcus aureus. J Am Dent Assoc 2012;143:270-277.

15. Costerton JW, Lewandowski Z, Caldwell DE, Korber DR, Lappin-Scott HM. Microbial biofilms. Annu Rev Microbiol 1995;49:711-745.

16. Pinto LR, Acosta EJ, Távora FF, Silva PM, Porto VC. Effect of repeated cycles of chemical disinfection on the roughness and hardness of hard reline acrylic resins. Gerodontology 2010;27:147-153.

17. Goiato MC, Dos Santos DM, Baptista GT, Moreno A, Andreotti AM, Bannwart LC, et al.. Effect of thermal cycling and disinfection on colour stability of denture base acrylic resin. Gerodontology 2012. [Epub ahead of print. DOI: 10.1111/j.1741-2358.2012.00676.x]

18. Bobichon $\mathrm{H}$, Bouchet P. Action of chlorhexidine on budding Candida albicans: scanning and transmission electron microscopic study. Mycopathologia 1987;100:27-35.

19. Gürgan CA, Zaim E, Bakirsoy I, Soykan E. Short-term side effects of $0.2 \%$ alcohol-free chlorhexidine mouthrinse used as an adjunct to non-surgical periodontal treatment: a double-blind clinical study. J Periodontol 2006;77:370-384.

20. Parr GR, Rueggerberg FA. In vitro hardness, water sorption, and resin solubility of laboratory-processed and autopolymerised long-term resilient denture liners over one year of water storage. J Prosthet Dent 2002;88:139-44.

21. Patel $P$, Ide $M$, Coward $P$, Di Silvio L. The effect of a commercially available chlorhexidine mouthwash product on human osteoblast cells. Eur J Prosthodont Restor Dent 2006;14:67-72.

22. Sheng WH, Wang JT, Lauderdale TL, Weng CM, Chen D, Chang SC. Epidemiology and susceptibilities of methicillin-resistant Staphylococcus aureus in Taiwan: emphasis on chlorhexidine susceptibility. Diagn Microbiol Infect Dis 2009;63:309-313.

23. Campanha NH, Pavarina $A C$, Brunetti IL, Vergani $C E$, Machado $A L$, Spolidorio DM. Candida albicans inactivation and cell membrane integrity damage by microwave irradiation. Mycoses 2007;50:140-147.

24. Dreyfuss MS, Chipley JR. Comparison of effects of sublethal microwave radiation and conventional heating on the metabolic activity of Staphylococcus aureus. Appl Environ Microbiol 1980;39:13-16.

25. Woo I, Rhee I, Park H. Differential damage in bacterial cells by microwave radiation on the basis of cell wall structure. Appl Environ Microbiol 2000;66: 2243-2247. 